\title{
Are We Asking the Right Questions?: A Response to the Academic Reforms Research the NCAA
}

\author{
Sarah K. Fields \\ The Ohio State University
}

\begin{abstract}
The purpose of this paper is to respond to the papers presented by Petr and McArdle (2012) and Paskus (2012). The author questions whether the appropriate issues are being addressed in broader academic reform efforts, and whether the data collected help the prime beneficiaries of intercollegiate athletics: the athletes. Questions pertaining to gender, race, and first-generation status are also posed.
\end{abstract}

Thank you, Todd (Petr \& McArdle, 2012) and Tom (Paskus, 2012), for sharing a wealth of information. Thanks as well to the National Collegiate Athletic Association (NCAA) and President Emmert for their support of this colloquium. Bringing your critics into your convention requires confidence and boldness. But the daring of our hosts is even broader. On November 3, 2011, the NCAA website posted an article about the academic colloquium, which quoted our program chair, Jack Evans. Jack acknowledged that some might fear this colloquium was heavily weighted with the NCAA's own, but he countered that "there will be reactors who speak from different perspectives, which I think will produce the type of dialog you would hope to have at a Colloquium" (Brown). Thanks, Jack, not just for your leadership in organizing this Colloquium, but also for issuing the challenge that inspired some of my remarks today. I do not, however, have so many remarks as I have questions-questions I hope will produce more dialogue about research, how it is being done, and its purpose for the NCAA, for college sport, and for the athletes themselves.

In an early version of their talk, Todd and Tom paraphrased Albert Einstein: "If we knew what we were doing, it wouldn't be called research." True enough. However, theoretical research, research for the pure joy and exploration of answering a question, is not really enough in today's world with today's issues.

In the scientific world, there has been a general push toward something called translational research. The National Cancer Institute at the National Institutes of Health defines it thus: "Translational research transforms scientific discoveries arising from laboratory, clinical, or population studies into clinical applications to reduce cancer incidence, morbidity, and mortality" (Translational Research Working Group, 2011). Drop the specific call to reduce cancer and you have the basic idea: transform academic discoveries into something that will make life better for

Fields is with Sport Humanities/Sport Management, Ohio State University, Columbus, OH. 
someone else. All of us at universities with medical centers have heard the call for translational research even in our nonmedical corners. While one could argue that part of the motivation for translational research might well be commercial, because whichever individual or institution discovers a cure for a cancer is likely going to be very, very rich, but the end result is not a bad thing - people will survive the disease.

And although our scientific and administrative brethren have discovered or rediscovered the concept of translational research within the last decade or so, the idea is much older. Praxis, a Latin word, is commonly translated as action or practice and it is the opposite of theory. In the early 18th century, the German philosopher Georg Wilhelm Friedrich Hegel argued that thought and action could be interrelated and connected. In 1845, Karl Marx pushed this line of argument further, proposing a model of "practical-critical" activity that combined theory with practice, thus maintaining that thinking could not be isolated from social action (Darity, 2008). In the humanities, more modern scholars have linked praxis to the idea of social justice, arguing that the best scholarship takes knowledge and pushes it into political action leading to more equitable communities (Wright, 2003). From praxis and translational research, comes the question I ask my students during their dissertation and theses defenses: what's the point? How does this research help someone besides you, the researcher?

This is one of the questions we must ask of the NCAA's research and of its scholarly interpretation. What's its point and are we asking the best questions? The organization has collected tremendous amounts of data regarding athletes' test scores, high school and college grade point averages, graduation rates, and all sorts of other quantifiable data. So what? How can that research be used to benefit the stakeholders in college sport?

Quite frankly, the only stakeholders in all this who really matter are the athletes themselves. The general student body, alumni, and boosters have an interest in college sport, but only as vested consumers and fans. Most of them do not care as much about the academic progress or achievements of the athletes as they do about their team's win-loss record. The faculty and general staffs at the university have, for all practical purposes, ceded control over athletics to the athletic department and the president, and they range from unabashed fans to cynical critics. The athletic staffs have their own agendas and this research can be used to make them look good or bad, but their interest in college sport is often largely financial: winning teams can make reputations, can generate money, and can create new opportunities for the coaches and staffs. This research does not necessarily help any of these stakeholders in college sport because the research is about the academics and the education of the athletes. As President Emmert once said, "Our mission is to be an integral part of higher education and to focus on the development of our student-athletes" (On the Mark, 2011). It is about the athletes.

We call our athletes student-athletes in part because we do not directly pay them. Their athletic scholarships and their opportunity to get an education is a large part of the justification for not paying them. So we must ask: how can this data benefit them as students?

Much of the information has been used to drive initial and subsequent eligibility. On the surface this seems perfectly reasonable; we can see from the data that more athletes have graduated since the implementation of eligibility requirements. However, so too have the graduation rates of students as a whole; thus, we cannot 
be certain that the rising graduation rates of all students would not have raised the rates of athletes as well. Given the long tradition of universities admitting athletes who fall below the averages of the general student body in areas of grade point average and test scores (Bowen \& Shulman, 2001), though, it seems likely that the initial eligibility standards at least helped the admitted athletes to be somewhat better prepared for their college coursework. In other words, the rising tide of student standards may not have carried the athletes up without the external, initial eligibility standards imposed by the NCAA. The idea that initial eligibility standards did help athletes graduate at higher rates is supported by the data showing that the class entering in 1986, the first of the Proposition 48 students, was the first class of athletes to graduate at higher rates according to the Federal Graduation Rate system than the general student body from Division I schools. So we could argue that these data illustrate initial eligibility standards protect athletes from greedy universities willing to exploit the student's athletic prowess, knowing that the athlete likely lacked the academic skill set to acquire a meaningful education at that institution. This research, therefore, seems to benefit the athletes, but we should begin to think of ways to determine if athletes' graduation rates are rising with the tide, if they are rising because of the academic reforms, or if other factors are at work.

Another major focus of research presented to us today revolves around the academic progress rate (APR), which is designed to measure the success of teams in moving their athletes toward graduation. This is a laudable goal, and thus it seems that the research tracking its effectiveness should directly benefit the athletes, but again we need to ask are these the right or best questions? Is the APR, the tracking toward a degree, the most important focus of research to best benefit the athletes?

"Our 'reason for being' is to assist our members in providing the best educational and athletic experience for student-athletes," President Emmert said when he accepted the office (Focus on the future, 2010). Thus far the NCAA data have focused on measuring educational experience by progress toward degree and graduation rates. Getting a degree from a college or university is an excellent accomplishment and improves job prospects dramatically. ${ }^{1}$ The reality of finding employment in these challenging economic times, though, is that many other things such as major and connections make a difference. We need to track not just the graduation rates and the majors but also the job placement of our athletes. We need to ask them how they got those jobs to make sure that all our athletes, and not just those from high-profile sports, benefit from their sporting experience. As the advertisement says, just about all of the 400,000 NCAA athletes will be going pro in something other than sports. Our research should focus at least in part on how to help all of them get there.

Although graduation rates are important, there should be more to college than just the degree. One of the shameful secrets of university life is it is certainly possible to earn a degree without really learning much of anything. The education occurring on university campuses, can, should, and does happen in a variety of locations outside of the classroom and the library. It happens over meals and drinks, in conversations and arguments with friends and roommates, in supplemental lectures and exhibits, and in the locker rooms as well as on the playing fields. I believe that the value of a physical university as opposed to an on-line education is the education that occurs via live, rather than virtual, interaction and engagement with other people and ideas. I do not know how to quantify the education our athletes receive, but perhaps this is an area we should consider. In part we need to consider how much 
time our athletes are spending on their sport and at what cost that poses to their off-field and out-of-classroom education. The Growth, Opportunities, Aspirations, and Learning of Students in College (GOALS) data that Paskus (2012) presented indicate athletes are spending upwards of 70 hours a week on athletics and academics, leaving them very little time to participate in the educational opportunities outside of the classroom and the sporting fields. This may well be comparable to the division of labor among students who are active in student government, music, or theater, but we do not know. Knowing what the athletes lose as students because of their commitment to sport would be worthwhile. Similarly as Paskus (2012) points out, we need to better understand the choices athletes make regarding majors and courses and work to determine how much of their academic decisions are being driven by their athletic commitments.

Not only do we need to ask how our research benefits our athletes, we need to consider if we are asking the right questions. One of the questions asked repeatedly throughout the data collection process is what the gender and race of the athlete is. Gender is an interesting question. In the 21 st century, our students have much more fluid concepts of gender and are more open about those concepts than in the past. In 2010-2011, we had our first out transgender Division I athlete compete in basketball only to announce he would not return to the team the following year (Garcia, 2011). Thus, we need to begin to rethink how we ask our questions about gender. We need to figure out the purpose of the question (are we going to stop offering services to the gender that is more academically successful?), and we need to ask if we are using gender as a proxy for something else. Is a better question what the athlete's sport is and if there are viable domestic professional opportunities in that sport?

Regarding race, given that the initial eligibility standards have traditionally been based on some combination of test-score and high school grade point average and that the test-scores have long been shown to have a disparate impact on people of color, then arguably the question about race is relevant. But is it the best question? Our concept of race evolves, as illustrated by the United States Census allowing the option of being bi- or multiracial (U.S. Census Bureau, 2000). Thus, perhaps we need to rethink how race fits into the NCAA research and ask what is race and how should we ask about it and identify it? And why do we need to know it? Further, we must ask why the NCAA data focuses on the Black-White divide, largely ignoring all other races and ethnicities. Yes, most athletes are African-American or White, so perhaps another question we must ask is where is everyone else? Why are they not on our teams in sufficient numbers that we quantify and report their scores and graduation rates?

Another question we should ask is about a different at-risk group that has only recently garnered scholarly attention. First-generation students are defined as those who have not had a parent or guardian graduate from a four-year college. This group includes underrepresented racial and ethnic minorities as well as students from lower socioeconomic status families. Research suggests that these students are more likely to drop out of college and, of those who stay, are less likely to graduate in a timely manner and likely to get less out of their college education (Davis, 2010). Some of them are athletes, and we need to know how to help these students maximize their educational opportunities.

I want to conclude by noting that I have asked a number of questions. Todd and Tom and their office may well have this information. They have a lot of information, 
and they had a limited amount of time in which to share it. If my questions have already been answered and data are being collected, it becomes imperative that the NCAA and scholars work together to analyze and disseminate that material. Research for research's sake does no one beyond the researcher any good. We must share the information with other scholars and the athletes themselves, and further we must translate that research into policies and practices that benefit our athletes.

\section{Note}

1. Among adults over the age of 25 , unemployment for those with a Bachelors degree or higher had unemployment rates in November 2011 of about $4.4 \%$-well below the $8.8 \%$ unemployment rate of those with just a high school degree but both statistics exclude discouraged and long-term unemployed. In June 2011, unemployment rates among recent college graduates between the ages of 20 and 24 were over 12\% (Fairbanks \& Lenoir, 2011).

\section{References}

Bowen, W.G., \& Shulman, J.L. (2001). The game of life: College sports and educational values. Princeton, NJ: Princeton University Press.

Brown, G. (2011, November 3). Colloquium shines research spotlight on academic reform. Retrieved from http://www.ncaa.org/wps/wcm/connect/public/NCAA/Resources/ Latest+News/2011/November/Colloquium+shines+research+spotlight+on+academic +reform

Darity, W.A., Jr., (Ed.). (2008). Praxis. In International encyclopedia of the social sciences (2nd ed.). (pp. 421-422). Detroit, MI: Macmillan Reference. Retrieved from http:// go.galegroup.com

Davis, J. (2010). The first-generation student experience: Implications for campus practice, and strategies for improving persistence and success. Sterling, VA: Stylus Publishing, LLC.

Fairbanks, A.M., \& Lenoir, A. (2011, September 7). Jobless college graduates struggle under ongoing recession. Retrieved from http://www.huffingtonpost.com/2011/07/08/ college-graduates-jobs-unemployment_n_893495.html

Focus on the future. (2010, August 13). Retrieved from http://www.ncaa.org/wps/wcm/connect/ public/NCAA/Resources/Latest+News/2010+news+stories/August+latest+news/ $\mathrm{NCAA}+$ President-Elect+Mark+Emmert+outlines+his+vision

Garcia, M. (2011, May 19). Kye Allums leaving basketball. The Advocate. Retrieved from http:// www.advocate.com/News/Daily_News/2011/05/19/Kye_Allums_Leaving_Basketball/

National Cancer Institute, National Institutes of Health, Translational Working Research Group. (2011). TRWG Definition of Translational Research. Retrieved from http:// www.cancer.gov/researchandfunding/trwg/TRWG-definition-and-TR-continuum

On the Mark: Quotes from President Emmert on various NCAA topics. (2010, October 5). Retrieved from http://www.ncaa.org/wps/wcm/connect/public/NCAA/ NCAA+President/On+the+Mark

Paskus, T. (2012). A summary and commentary on the quantitative results of current NCAA academic reforms. Journal of Intercollegiate Sport, 5, 41-53.

Petr, T.A., \& McArdle, J.J. (2012). Academic research and reform: A history of the empirical basis for NCAA academic policy. Journal of Intercollegiate Sport, 5, 27-41.

U.S. Census Bureau. (2000). Questions and answers for Census 2000 data on race. Retrieved from http://www.census.gov/census2000/raceqandas.html

Wright, H.K. (2003). Cultural studies as praxis: (Making) an autobiographical case. Cultural Studies, 17, 805-822. doi:10.1080/0950238032000150039 